\title{
Environmental inactivation and irrigation-mediated regrowth of Escherichia coli 0157:H7 on romaine lettuce when inoculated in a fecal slurry matrix
}

\author{
Jennifer A Chase ${ }^{\text {Corresp., }}{ }^{1}$, Melissa L Partyka ${ }^{2}$, Ronald F Bond ${ }^{1}$, Edward R Atwill ${ }^{\text {Corresp. } 1}$ \\ ${ }^{1}$ Western Center for Food Safety, University of California, Davis, Davis, California, United States \\ 2 School of Fisheries, Aquaculture and Aquatic Sciences, Auburn University, Auburn, Alabama, United States \\ Corresponding Authors: Jennifer A Chase, Edward R Atwill \\ Email address: jachase@ucdavis.edu, ratwill@ucdavis.edu
}

Field trials were conducted in July-August and October 2012 to quantify the inactivation rate of Escherichia coli 0157:H7 when mixed with fecal slurry and applied to romaine lettuce leaves. Lettuce was grown under commercial conditions in Salinas Valley, California. One-half milliliter of rabbit, chicken, or pig fecal slurry, containing an average of 4.05 $\times 10^{7}$ CFU E. coli 0157:H7 $\left(\mathrm{C}_{0}\right)$, was inoculated onto the upper (adaxial) surface of a lower leaf on 288 heads of lettuce per trial immediately following a $2.5 \mathrm{~h}$ irrigation event. To estimate the bacterial inactivation rate as a function of time, fecal matrix, irrigation, and seasonal climate effects, sets of lettuce heads $(n=28)$ were sampled each day over 10 days and the concentration of E. coli 0157:H7 $\left(C_{t}\right)$ determined. E. coli 0157:H7 was detected on $100 \%$ of heads during the 10-day duration, with concentrations ranging from $\leq 340 \mathrm{MPN} /$ head ( $~ 5-\log$ reduction) to $>3.45 \times 10^{12} \mathrm{MPN} /$ head ( $~ 5-\log$ growth). Relative to $\mathrm{C}_{0}$, on day $10\left(\mathrm{C}_{\mathrm{t}=12}\right)$ we observed an overall 2.6-log and 3.2-log mean reduction of $E$. coli 0157:H7 in July and October, respectively. However, we observed relative maximum concentrations due to bacterial growth on day 6 (maximum $\mathrm{C}_{\mathrm{t}=8}$ ) apparently stimulated by foliar irrigation on day 5. From this maximum there was a mean 5.3-log and 5.1-log reduction by day $10\left(\mathrm{C}_{\mathrm{t}=12}\right)$ for the July and October trials, respectively. This study provides insight into the inactivation and growth kinetics of $E$. coli $0157: \mathrm{H} 7$ on romaine lettuce leaves under natural field conditions. This study provides evidence that harvesting within 24 hours post irrigation has the potential to increase the concentration of E. coli O157:H7 contamination, if present on heads of romaine lettuce; foliar irrigation can temporarily stimulate substantial regrowth of $E$. coli O157:H7. 


\section{Environmental inactivation and irrigation-mediated}

2 regrowth of Escherichia coli $0157: H 7$ on romaine lettuce

\section{3 when inoculated in a fecal slurry matrix}

4

5 Jennifer A. Chase ${ }^{1}$, Melissa L. Partyka ${ }^{2}$, Ronald F. Bond ${ }^{1}$, and Edward R. Atwill ${ }^{*}$

6

$7 \quad{ }^{1}$ Western Center for Food Safety, University of California, Davis, California, United States

$8{ }^{2}$ School of Fisheries, Aquaculture, and Aquatic Sciences, Auburn University, Alabama, United States

$20 *$ Corresponding author:

21 Edward R. Atwill ${ }^{1}$

221089 Veterinary Medicine Dr. Davis CA 95616, United States

23 E-mail address: ratwill@ucdavis.edu 


\section{ABSTRACT}

25 Field trials were conducted in July-August and October 2012 to quantify the inactivation rate of

26 Escherichia coli O157:H7 when mixed with fecal slurry and applied to romaine lettuce leaves. Lettuce

27 was grown under commercial conditions in Salinas Valley, California. One half milliliter of rabbit,

28 chicken, or pig fecal slurry, containing an average of $4.05 \times 10^{7} \mathrm{CFU}$ E. coli $\mathrm{O} 157: \mathrm{H} 7\left(\mathrm{C}_{0}\right)$, was inoculated

29 onto the upper (adaxial) surface of a lower leaf on 288 heads of lettuce per trial immediately following a

$302.5 \mathrm{~h}$ irrigation event. To estimate the bacterial inactivation rate as a function of time, fecal matrix,

31 irrigation, and seasonal climate effects, sets of lettuce heads $(n=28)$ were sampled each day over 10 days

32 and the concentration of E. coli $\mathrm{O} 157: \mathrm{H} 7\left(\mathrm{C}_{\mathrm{t}}\right)$ determined. E. coli $\mathrm{O} 157: \mathrm{H} 7$ was detected on 100\% of

33 heads during the 10-day duration, with concentrations ranging from $\leq 340 \mathrm{MPN} /$ head ( $~ 5-\log$ reduction)

34 to $>3.45 \times 10^{12} \mathrm{MPN} /$ head $\left(\sim 5-\log\right.$ growth). Relative to $\mathrm{C}_{0}$, on day $10\left(\mathrm{C}_{\mathrm{t}=12}\right)$ we observed an overall 2.6-

$35 \log$ and 3.2-log mean reduction of E. coli O157:H7 in July and October, respectively. However, we

36 observed relative maximum concentrations due to bacterial growth on day 6 (maximum $\mathrm{C}_{\mathrm{t}=8}$ ) apparently

37 stimulated by foliar irrigation on day 5. From this maximum there was a mean 5.3-log and 5.1-log

38 reduction by day $10\left(\mathrm{C}_{\mathrm{t}=12}\right)$ for the July and October trials, respectively. This study provides insight into

39 the inactivation and growth kinetics of E. coli $\mathrm{O} 157: \mathrm{H} 7$ on romaine lettuce leaves under natural field

40 conditions. This study provides evidence that harvesting within 24 hours post irrigation has the potential

41 to increase the concentration of $E$. coli $\mathrm{O} 157: \mathrm{H} 7$ contamination, if present on heads of romaine lettuce;

42 foliar irrigation can temporarily stimulate substantial regrowth of E. coli $\mathrm{O} 157: \mathrm{H} 7$. 


\section{Introduction}

44

45

46

47

48

49

50

51

52

53

54

55

Consumption of contaminated fresh produce continues to be a significant cause of foodborne illness in the United States (US) (Richardson et al. 2017). For example, in 2015 there were 383 reported foodborne illnesses associated with leafy green vegetables, according to the US Centers for Disease Control and Prevention (CDC 2017). Despite a considerable amount of effort by private industry, academia, and governmental agencies to fully understand the core mechanisms and contributing factors responsible for microbial contamination in the preharvest environment, it is not known what proportion of the annual foodborne incidence of Escherichia coli $\mathrm{O} 157: \mathrm{H} 7$ or other pathogenic enteric bacteria are associated with produce is due to contaminated irrigation water, wildlife intrusion, or the use manurebased soil amendments in the preharvest production environment.

Research studies have been conducted to estimate the prevalence of pathogens in irrigation water supplies (Falardeau et al. 2017; Gorski et al. 2014; Partyka et al. 2018b; Ssemanda et al. 2018), survival kinetics of these pathogens in agricultural water (Steele \& Odumeru 2004; Wang et al. 2018), and how well pathogens survive once transferred onto crops via irrigation (Atwill et al. 2015; Chase et al. 2017; Moyne et al. 2011; Van Der Linden et al. 2014; Weller et al. 2017b). For example, numerous studies have shown the occurrence of bacterial pathogens in US agricultural water supplies, especially for surface water sources (Falardeau et al. 2017; Partyka et al. 2018a; Partyka et al. 2018b; Partyka et al. 2016). While contaminated irrigation water can act as a vehicle to directly transfer pathogens onto crops (BarkerReid et al. 2009; Erickson et al. 2010; Fonseca et al. 2011; Solomon et al. 2003; Solomon et al. 2002a; Wachtel et al. 2002), it has also been shown to transfer pathogens from either manure or manure-amended soil (Franz et al. 2008; Mootian et al. 2009; Solomon et al. 2002b); and simulated wildlife scat onto nearby lettuce heads (Atwill et al. 2015; Weller et al. 2017a).

These studies indicate that pathogen transfer onto crops can occur under specific conditions; less clear is the survival kinetics of these transferred pathogens once on the surface of produce and whether a sufficient proportion of pathogens survive to the point of harvest and thereby manifest as a food safety hazard. Pathogens such as E. coli $\mathrm{O} 157: \mathrm{H} 7$ deposited onto produce via irrigation water have been shown 
69 to experience high levels of log-reduction under summer field conditions (McKellar et al. 2014; Moyne et 70 al. 2011). However, a recent study under California summer conditions found that E. coli $\mathrm{O} 157: \mathrm{H} 7$ mixed 71 with a fecal slurry to simulate fecal splash during foliar irrigation exhibited reduced rates of inactivation 72 in contrast to this earlier work (Chase et al. 2017). In addition, Weller et al. (2017b) replicated these 73 findings of extended survival of $E$. coli when the bacteria were mixed in a fecal slurry under growing 74 conditions typical of upstate New York.

75 The present follow-up study was conducted to further characterize survival kinetics of E. coli 76 O157:H7 in wildlife fecal slurries applied to romaine lettuce to simulate fecal splash caused by foliar 77 irrigation, stratified by vertebrate sources of feces (rabbit, pig, chicken) and growing seasons (July78 August and October). In addition, the effect of irrigation on the population of inoculated bacteria was investigated by irrigating midway through the trial (day 5) to determine if irrigation had a significant effect on pathogen persistence on romaine lettuce leaves.

\section{Materials and methods}

\section{Field site and lettuce plot}

During the summer (July-August) and fall (October) of 2012, romaine lettuce (Lactuca sativa L. var. longifolia) was grown under commercial conditions in the Salinas Valley, California with plant thinning, weed removal, and irrigation being performed as needed up to field inoculation described by Chase et al. (2017). The lettuce was planted on June 12 and August 14 for the summer and fall trials, respectively. At the time of inoculation, lettuce plants were 60 days old from in-ground seed sowing and were in the head formation stage. The field plot (18.3 m wide x $90.5 \mathrm{~m}$ long) consisted of beds 56 to 61 $\mathrm{cm}$ wide separated by furrows 40 to $46 \mathrm{~cm}$ wide; each bed contained two parallel rows of lettuce separated by $30.5 \mathrm{~cm}$ at time of planting. A subplot of 20 adjacent beds within the experimental field plot were allocated for this bacterial inactivation study. Lettuce heads were randomly selected for inoculation and identified by placing a color-coded stake flag, labeled with the lettuce head collection ID, directly 
95

roughly $3.5 \mathrm{~h}$ and $2.5 \mathrm{~h}$ with a mean cumulative water application of $3.35 \mathrm{~cm}$ and $2.41 \mathrm{~cm}$, respectively. Field maintenance (e.g. irrigation, plant thinning, weed removal) were halted for the remainder of the experiment, apart from a planned mid-trial foliar irrigation event. The mid-trial foliar irrigation event occurred in the morning, five days post-inoculation for $2.65 \pm 0.12 \mathrm{~h}$ during which an average $2.59 \mathrm{~cm}$ and $2.41 \mathrm{~cm}$ of water was applied on 8/1/2012 and 10/21/12, respectively. The amount of water applied during each irrigation event was determined using an online irrigation and management tool Crop Manage available at https://cropmanage.ucanr.edu.

\section{Weather data}

Hourly meteorological data was collected through the California Irrigation Management Information System (CIMIS), including; cumulative solar radiation $\left(\mathrm{W} / \mathrm{m}^{2}\right)$, air temperature $\left({ }^{\circ} \mathrm{C}\right)$, evapotranspiration $(\mathrm{ETo}, \mathrm{mm})$, relative humidity $(\%)$, wind speed $(\mathrm{m} / \mathrm{s})$ and direction $\left({ }^{\circ}\right)$, soil temperature $\left({ }^{\circ} \mathrm{C}\right)$ and rainfall $(\mathrm{mm})$ (Table S1). CIMIS station 116 (latitude $36^{\circ} 43^{\prime} 1.0^{\prime \prime} \mathrm{N}$, longitude: $-121^{\circ} 41^{\prime} 31.0^{\prime \prime} \mathrm{W}$ ) was chosen based on proximity and by the recommendation from the ETo Zone brochure available on the CIMIS website (www.cimis.water.ca.gov), which was $\sim 2.5 \mathrm{~km}$ from the study plots (latitude: $36^{\circ} 37^{\prime} 41.8^{\prime \prime} \mathrm{N}$, longitude $\left.121^{\circ} 32^{\prime} 26.4^{\prime \prime} \mathrm{W}\right)$. An additional HOBO weather station was placed within the lettuce plots and leaf wetness (\%) in fifteen-minute intervals. No recorded precipitation occurred during either trial. However, typical to the area, there was an early morning marine layer that gradually cleared by mid-day due to seasonal prevailing northwest wind patterns in Salinas Valley; the winds increase during the day due to the pinching of airflow through the Mount Diablo and Santa Lucia mountain ranges.

\section{Bacterial strain}

We used a rifampicin resistant $(50 \mu \mathrm{g} / \mathrm{mL})$ E. coli O157:H7 strain ATCC 700728 that lacked Stx 1 and 2 genes (Atwill et al. 2015; Chase et al. 2017; Moyne et al. 2011). Bacterial cultures were grown in Tryptic Soy Broth (TSB) (Difco, BD, Sparks, MD) supplemented with $50 \mu \mathrm{g} / \mathrm{mL}$ rifampicin (+R) (Gold Biotechnology, St. Louis, Missouri USA) and incubated at $37^{\circ} \mathrm{C}$ for $6 \mathrm{~h}$ with orbital rotation (100 rpm). 
121 Cell counts were first estimated using a regression equation that extrapolated bacterial concentration from

122 the optical density (OD, $600 \mathrm{~nm}$ ), then confirmed by serial dilution in Phosphate Buffer Saline (PBS)

123 (Sigma-Aldrich St. Louis, Missouri USA) and spread plate onto Tryptic Soy Agar (Difco, BD, Sparks,

$124 \mathrm{MD})$ supplemented with $+\mathrm{R}(\mathrm{TSA}+\mathrm{R})$ and incubated at $37^{\circ} \mathrm{C}$ for $18-24 \mathrm{~h}$.

Fecal slurry and spiking with $E$. coli $0157: \mathrm{H7}$

Fecal material was collected within twenty-four hours of slurry construction from three species: scrofa domesticus) housed at the Teaching and Research Animal Care Services (TRACS) Facility, Hopkins Avian Facility, and the Swine Teaching and Research Center, respectively, all located at the University of California, Davis. These three sources of fecal material were selected for inclusion in this study because growers and researchers have consistently observed these wildlife species (avian, rodents, feral pigs) intruding into and defecating in agricultural fields of central coastal California. In addition, using laboratory animal populations housed at UC Davis allowed us to reasonably control for fecal consistency and mammalian source of feces. The rabbit cages and chicken coop had been cleaned within twelve hours of collection. The pig fecal material was freshly voided within two hours of collection. Fecal samples were pooled from multiple individuals housed in their respective TRACS facilities. Feces used in the experiments were confirmed negative for E. coli $\mathrm{O} 157: \mathrm{H} 7$ and rifampicin resistant non-O157 E. coli. Fecal slurries (rabbit, chicken, or pig) were constructed as described in Chase et al. (2017), modified using a fecal-PBS ratio of $1 \mathrm{gm}: 4 \mathrm{~mL}$. Briefly, feces and PBS were stomached in a 55-oz Whirl-Pak filter Inc., Bohemia, NY) for 5 min at $230 \mathrm{rpm}$; the liquid portion was dispensed into a sterile flask, vortexed for $1 \mathrm{~min}$, then inoculated with a target concentration of E. coli $\mathrm{O} 157: \mathrm{H} 7$. Prior to use, the slurries were homogenized by vigorous shaking for $1 \mathrm{~min}$. Slurries were stored at $4{ }^{\circ} \mathrm{C}$ for approximately twelve hours prior to field inoculations. E. coli $\mathrm{O} 157: \mathrm{H} 7$ concentrations were confirmed using the serial dilution spread 
147 immediately following construction and again immediately before field inoculations to confirm no

148 significant growth or death occurred during the twelve-hour refrigeration hold.

149 During each trial, 288 lettuce heads were inoculated with one of the three fecal slurries (96 heads

150 per fecal type); the slurry was applied directly onto the adaxial (upper) surface of a lower outer leaf.

151 During the July and October trials, the $0.5 \mathrm{~mL}$ of slurry inoculum contained an average of $3.90 \times 10^{7}$ and

$1524.20 \times 10^{7} \mathrm{CFU}$ E. coli O157:H7, respectively (Table 1).

153

154 Collection of lettuce

155 Twelve collection events occurred over a ten-day (236 hours) period. Collection times varied

156 slightly over the two fields trials; the average collection time (h) since inoculation ( $\mathrm{t}=$ event: day)

157 included: $0.5 \pm 0.3 \mathrm{~h}(\mathrm{t}=1: 0.02), 21.8 \pm 0.8 \mathrm{~h}(\mathrm{t}=2: 0.9), 44.6 \pm 0.1 \mathrm{~h}(\mathrm{t}=3: 1.9), 68.9 \pm 0.4 \mathrm{~h}(\mathrm{t}=4: 2.9)$,

$15893.3 \pm 0.5 \mathrm{~h}(\mathrm{t}=5: 3.9), 115.9 \pm 0.1 \mathrm{~h}(\mathrm{t}=6: 4.8), 121.3 \pm 1.8 \mathrm{~h}(\mathrm{t}=7: 5.1), 141.8 \pm 0.5 \mathrm{~h}(\mathrm{t}=8: 5.9), 164.9 \pm 0.4$

$159(\mathrm{t}=9: 6.9), 188.5 \pm 0.5 \mathrm{~h}(\mathrm{t}=10: 7.9), 212.8 \pm 0.3 \mathrm{~h}(\mathrm{t}=11: 8.9)$, and $235.4 \pm 0.6(\mathrm{t}=12: 9.8)$. A total of 24 heads

160 of lettuce were harvested per collection event, with eight heads per fecal slurry type, using methods

161 described by Atwill et al. (2015) and Chase et al. (2017). Briefly, lettuce was aseptically harvested and

162 placed in a $24 \times 24$ Bitran bag (Uline, Pleasant Prairie, WI); after each head was harvested, the sampler put

163 on a new pair of gloves and cleaned the harvesting knife with 70\% ethanol. We adhered to a strict QAQC

164 protocol using both laboratory and field controls; in addition to using laboratory positive and negative

165 controls, negative field control heads $(n=4)$ were also collected each day from a negative control plot

166 immediately adjacent to the experimental plot and processed using the same protocol as the inoculated

167 heads. To confirm that the irrigation water was not a source of the target organism, $20 \mathrm{~L}$ of water was

168 collected from a single sprinkler head in sterile carboy (Nalgene Nunc, Penfield, NY) during each

169 irrigation event $(n=4)$. Inoculated and negative control lettuce samples, as well as the water samples, were

170 placed on ice $\left(\sim 4^{\circ} \mathrm{C}\right)$ and transported to UC Davis for analysis.

172 Bacterial enumeration and confirmation of $E$. coli $\mathbf{O 1 5 7 : H 7}$ 
174 were processed methods previously described by Atwill et al. (2015) and Chase et al. (2017) which is

175 designed to enumerate a wide range of bacterial concentrations; with the lower limit of enumeration being

$1760.68 \mathrm{MPN} / \mathrm{mL}$ washate (equilaent to $340 \mathrm{MPN} /$ whole head of lettuce) and the upper limit of enumeration

177 being $6.9 \times 10^{9} \mathrm{MPN} / \mathrm{mL}$ washate (equivalent to $3.45 \times 10^{12} \mathrm{MPN} /$ whole head of lettuce). Briefly, a $500 \mathrm{~mL}$

178 PBS $+\mathrm{R}$ washate was added to each sampling bag containing a head of lettuce. Samples were lightly

179 massaged and vigorously shaken to detach E. coli $\mathrm{O} 157: \mathrm{H} 7$ cells from the lettuce surface into solution.

180 The concentration of $E$. coli $\mathrm{O} 157: \mathrm{H} 7$ was determined by transferring $1 \mathrm{~mL}$ of the PBS washate into the

181 first two positions of a 12-well-deep reservoir (VWR, Radnor, PA) containing $9 \mathrm{~mL}$ TSB $+\mathrm{R}$, followed by

182 duplicate 100 -fold serial dilutions the remaining 10 wells containing $9.9 \mathrm{~mL}$ TSB+R. Sample reservoirs

183 were incubated at $37^{\circ} \mathrm{C}$ for $24 \mathrm{~h}$ with orbital rotation of $50 \mathrm{rpm}$. The sample enrichments were channel

184 struck, using a 12-channel pipette, onto CHROMagar O157 (CHROMagar, Paris, France) supplemented

185 with $+\mathrm{R}$ and incubated at $37^{\circ} \mathrm{C}$ for $24 \mathrm{~h}$. Bacterial concentrations were estimated using two MPN

186 calculators (Curiale ; Jarvis et al. 2010) then extrapolated from a per-mL to a per-head outcome by

187 multiplying by 500 (volume of washate per head of lettuce). The sensitivity of this MPN assay was

188 determined using laboratory positive controls, set up as triplicate 10-fold serial dilutions ranging from

$1895.15 \times 10^{6} \mathrm{CFU}$ to $5.15 \times 10^{1} \mathrm{CFU}$ of $E$. coli $\mathrm{O} 157: \mathrm{H} 7$. Each bacterial suspension was inoculated onto a

190 head of lettuce, held for four hours under refrigeration to account for transportation time, and the assay

191 performed as described above. All positive control heads of lettuce tested positive, and the MPN

192 estimates generally matched the expected values of the 10 -fold serial dilutions $\left(5.15 \times 10^{6} \mathrm{CFU}\right.$ to

$1935.15 \times 10^{1} \mathrm{CFU}$ of $E$. coli $\left.\mathrm{O} 157: \mathrm{H} 7\right)$

Isolates from a subset of samples $(n=60)$ were confirmed by PCR, followed by pulsed-field gel electrophoresis to confirm isolates matched our original inoculum, as described by Atwill et al. (2015) and Chase et al. (2017). Water samples were analyzed using ultrafiltration methods described in Partyka et al. (2018a) and all samples were confirmed negative. 
199

200

201

202

203

204

205

206

207

208

209

210

211

212

213

214

215

216

217

218

219

220

221

222

223

224

\section{Statistical analysis}

Negative binomial regression was used to model the daily concentration of E. coli $\mathrm{O} 157: \mathrm{H} 7$ on heads of romaine lettuce over the two 10-day trials using STATA ${ }^{\circledR} 14$ software (StataCorp LP College Station, TX). The outcome of interest was the estimated (MPN) concentration of E. coli $\mathrm{O} 157: \mathrm{H} 7 /$ head $\left(\mathrm{C}_{\mathrm{t}}\right)$ as a function collection event $(\mathrm{t})$ with the inclusion of an offset variable $\left(\mathrm{C}_{0}\right)$ to account for the varying inoculum concentrations described in Table 1. Outcomes that exceeded the bounds of detection using the MPN methods described above were excluded from analysis: ten samples were positive only after enrichment ( $<340 \mathrm{MPN} /$ head) and three samples were TNTC $\left(>3.45 \times 10^{12} \mathrm{MPN} / \mathrm{head}\right)$. Additional covariates and interaction terms were included to help explain the variability in our observed data. In this study we adhered to a detailed model-fitting protocol as described by Partyka et al. (2017): final models were selected based on a combination of link-test, likely-hood ratio test, AIC score and pseudo- $\mathrm{R}^{2}$. The link-test was used to confirm that our dependent variable was properly specified, which resulted in a significant linear predictor $(P=0.000)$ and insignificant $(P=0.348)$ linear predictor squared.

\section{Results}

Five hundred and seventy-two inoculated heads of lettuce were collected and processed during two separate 10-day (236 h) field trials in July-August $(n=287)$ and October $(n=285)$ of 2012; four samples were excluded from processing due to faulty collection bags. Concentrations of E. coli $\mathrm{O} 157: \mathrm{H} 7$ in the $0.5 \mathrm{~mL}$ inocula per head of lettuce $\left(\mathrm{C}_{0}\right)$ were similar between both trials, ranging from $3.76 \times 10^{7}$ to $4.17 \times 10^{7} \mathrm{CFU}$ for the July trial and $3.03 \times 10^{7}$ to $5.00 \times 10^{7} \mathrm{CFU}$ in the October trial. Results of laboratory analyses were recorded as MPN/head of lettuce $\left(\mathrm{C}_{t}\right)$ and standardized for statistical analysis using the offset option for negative binomial regression to account for variability in initial inoculum concentration $\left(\mathrm{C}_{0}\right)$ shown in Table 2 . Nearly all heads of lettuce $(559 / 572,97.7 \%)$ had quantifiable concentrations of bacteria during the 10-day trial; in ten samples, E. coli O157:H7 were detectable only after enrichment ( $<340 \mathrm{MPN} /$ head, lower enumeration limit) and the upper enumeration limit $\left(>3.45 \times 10^{12} \mathrm{MPN} / \mathrm{head}\right)$ was exceeded in three samples (Table 1). This indicates that none of the heads of lettuce experienced greater 
225

226

227

228

229

230

231

232

233

234

235

236

237

238

239

240

241

242

243

244

245

246

247

248

249

than 7.5- to 7.7-log reduction relative to $\mathrm{C}_{0}$ during the pair of 10-day trials for three fecal matrices (pig, rabbit, chicken) and two seasons, with many heads of lettuce experiencing substantially less reductions in E. coli $\mathrm{O} 157: \mathrm{H} 7$. In terms of general trends averaged across the three fecal matrices, we observed a mean 2.6- and 3.2-log reduction compared to initial concentrations $\left(\mathrm{C}_{0}\right)$ in July and October, respectively, but given the likely regrowth of E. coli $\mathrm{O} 157: \mathrm{H} 7$ following foliar irrigation discussed below, the mean $\log$ reduction on day 10 relative to $\mathrm{C}_{\max }$ on day $6\left(\mathrm{C}_{\mathrm{t}=8}\right)$ ranged from 5.1 to 6.7 (Table 1, Fig. 1).

Hourly weather data were retrieved from two nearby CIMIS weather stations beginning $24 \mathrm{~h}$ before the start of each trial and continuing through the final day of collection to calculate daily averages and ambient conditions during the 24 hours before collection (Table S1). Prior to completion of the October 2012 trial, the closest CIMIS weather station (\#89) was deactivated, requiring use of an alternative station (CIMIS \#116) more than $2 \mathrm{~km}$ away. For consistency, only data from site \#116 were utilized in comparisons between the trials for weather characteristics, in addition leaf wetness was collected by the onsite HOBO station. There was no measurable precipitation recorded during either trial. Average air temperature $\left({ }^{\circ} \mathrm{C}\right)$ during the trials was significantly higher in October $(P<0.0002)$ than July, with higher maximum $(P<0.0001)$ and lower minimum temperatures $(P<0.0001)$ (Table S1). Although long summer days in July produced higher average solar radiation $\left(\mathrm{W} / \mathrm{m}^{2}\right)(P<0.0046)$ than recorded in October, July also experienced multiple days of dense morning fog leading to significantly higher average humidity $(P<0.0001)$ and warmer soil temperatures $(P<0.0001)$ and overall cooler weather (Table S1). Air temperature, averaged across days-since-inoculation, was positively associated $(P<0.0001)$ with logtransformed E. coli O157:H7 concentrations for both July $\left(\beta=0.54, \mathrm{R}^{2}=0.08\right)$ and October $(\beta=0.44$, $\left.\mathrm{R}^{2}=0.33\right)$; however, all weather variables except for leaf wetness were non-significant $(P>0.05)$ in the final model of E. coli $\mathrm{O} 157: \mathrm{H} 7$ concentration on heads of romaine lettuce, when collection event was introduced as a covariate (Table 2). This lack of significance for most weather variables when time-sinceinoculation was included in the regression model is likely due to collinearity between time-sinceinoculation and these other weather variables. 
251

252

253

254

255

256

257

258

259

260

261

262

263

264

265

266

267

268

269

270

271

272

273

was a significant reduction in the concentration of E. coli $\mathrm{O} 157: \mathrm{H} 7$ throughout the duration of the

October trial relative to the earlier trial, which we hypothesize is the consequence of bacterial growth during cool, wet conditions during the early phase of the July-August trial. Twenty-four-hour leaf wetness was positively associated with $E$. coli $\mathrm{O} 157: \mathrm{H} 7$ concentration throughout the trial; each additional percent increase of wetness was associated with $\sim 4.2 \%\left(\mathrm{e}^{0.041 \times 1}=1.042\right)$ increase in the concentration of $E$. coli O157:H7 per lettuce head (Fig. 2). We observed a substantial increase of E. coli O157:H7 during the initial two days $(\leq 44.75 \mathrm{~h})$ post-inoculation for both trials, but especially during the July-August trial. Approximately 55\% $(n=37)$ of the inoculated heads of lettuce exhibited higher bacterial concentrations consistent with bacterial growth relative to the original inoculum dosage $\left(\mathrm{C}_{0}\right)$ during the first two days of the July trial, while only $\sim 24 \%(n=17)$ of heads of lettuce exhibited bacterial concentrations above $\mathrm{C}_{0}$ in the October trial. This difference in bacterial growth in the early part of the July trial compared to October resulted in a significant seasonal effect in the regression model (Table 2), with $\mathrm{C}_{t>0}$ values in October having on average $\sim 98.3 \%$ less $\left(\mathrm{e}^{-4.066 \times 1}=0.017\right)$ compared to July-August trial. During the cooler and wetter July trial, lettuce heads inoculated with the pig slurry accounted for the majority $(42 \%, n=25)$ of total lettuce samples above $\mathrm{C}_{0}$, with $32 \%(n=19)$ and $26 \%(n=15)$ of lettuce heads above $\mathrm{C}_{0}$ inoculated with rabbit and chicken slurry, respectively. However, during the October trial, lettuce heads inoculated with the pig slurry accounted for a minority $19 \%(n=4)$ of the samples with bacterial concentrations above $\mathrm{C}_{0}$, while $33 \%(n=7)$ and $48 \%(n=10)$ of lettuce heads exhibiting bacterial concentrations above $\mathrm{C}_{0}$ were inoculated with rabbit and chicken slurry. This inverse relationship between fecal matrix source and the proportion of lettuce heads exhibiting growth above $\mathrm{C}_{0}$, explains the significant interaction term of fecal matrix $\times$ trial included in the final model (Table 2): both rabbit and chicken fecal matrix terms have $>2.0$ coefficients for their interaction with October, which results in a combined coefficient (main effect + interaction term) greater than 0 which is the referent value for pig slurry. Differences in the microbiota 
274 and nutritional composition of the mammalian fecal material used between the two trials (i.e., different

275 laboratory animals) may help explain the differing effects of fecal matrix between trials.

276 Given the complex nature of how E. coli $\mathrm{O} 157: \mathrm{H} 7$ behaved on the surface of lettuce leaves as a

277 function of time-since-inoculation, fecal matrix, and environmental or weather variables, multiple

278 regression models were considered. For example, regression equations with quadratic and higher order

279 variables for time-since-inoculation as a continuous variable were considered to adequately describe

280 bacterial populations $\left(\mathrm{C}_{\mathrm{t}}\right)$ on each head of lettuce over time. However, setting time-since-inoculation as a

281 categorical variable allowed a better fit to the complex raw data, especially given the significant multi-log

282 increase in $\mathrm{C}_{\mathrm{t}}$ values immediately after the irrigation event and reaching a maximum observed

283 concentration on day 6 (Tables 2 and 3, Fig. 1). For example, the average $\mathrm{C}_{\mathrm{t}=6}$ immediately before

284 irrigation (day 5) and one-day post-irrigation $\left(\mathrm{C}_{\mathrm{t}=8}\right.$, day 6 ) went from $1.11 \times 10^{8}$ to $4.50 \times 10^{11} \mathrm{MPN} / \mathrm{head}$

285 and from $1.24 \times 10^{6}$ to $3.23 \times 10^{9} \mathrm{MPN} /$ head in July and October, respectively (Table 1$)$. Irrigation-

286 mediated bacterial regrowth was not consistent across slurry matrices or trials; for pig, rabbit and chicken

287 we observed a mean regrowth $\left(\log _{10}\left[\mathrm{C}_{\mathrm{t}=6 \text { (pre-irrigation) }} / \mathrm{C}_{\mathrm{t}=8}\right]\right)$ of 3.4-, 3.7- and 4.8-log for the July samples

288 compared to 4.8-, 1.2- and 2.3-log in October, respectively. We speculate that there were shifts in the

289 slurry microbiota or interactions between the slurry type and microclimates that could have contributed to

290 these fluctuations. The peak in $C_{t}$ values on day $6\left(C_{t=8}\right)$ was quickly followed by a multi-log reduction on

291 day $7\left(\mathrm{C}_{\mathrm{t}=9}\right)$ to concentrations similar to days 4 and $5\left(\mathrm{C}_{\mathrm{t}=4}\right.$ and $\left.\mathrm{C}_{\mathrm{t}=5}\right)$ prior to foliar irrigation, followed by

292 bacterial tailing and brief regrowth (day $9, \mathrm{C}_{\mathrm{t}=11}$ ) during the remainder of the 10-day trial (Table 1, Fig. 1).

293 The subtle yet significant phase of $<1-\log$ regrowth 4 days after foliar irrigation (day $9, \mathrm{C}_{\mathrm{t}=11}$ ) was

294 observed in both the July-August and October trials.

295

296 Discussion

297

This project was the continuation of a multistate and multiyear effort coordinated by FDA to

298 examine how local environmental factors across the U.S. may influence the survival dynamics of fecal bacteria on lettuce under field conditions in order to better understand and predict potential food safety 
300

301

302

303

304

305

306

307

308

309

310

311

312

313

314

315

316

317

318

319

320

321

322

323

324

325

risks from consumption of produce. A study with similar design was conducted in upstate New York by Weller et al. (2017b) using methods based on Atwill et al. (2015), Chase et al. (2017), and this trial, in an effort to examine the behavior of bacterial pathogens under different field conditions. However, in the Weller et al. (2017b) study, a cocktail of rifampicin-resistant E. coli was used instead of the E. coli O157:H7 strain used in this study. In contrast to our current study which observed an overall average inactivation rate of $0.28 \log$ MPN day ${ }^{-1}$, Weller et al. (2017b) observed a higher inactivation rate of 0.52 $\log$ MPN day $^{-1}$ that was similar to the $\sim 0.6 \log$ MPN day $^{-1}$ observed by Chase et al. (2017). However, when the maximum recovered concentrations occurring at day 6 post-irrigation $\left(\mathrm{C}_{\mathrm{t}=8}\right)$ was used as the baseline for calculating the inactivation rate, the observed inactivation rate for this study was $\sim 1.32 \log$ MPN day ${ }^{-1}$ or 3-fold higher compared to Weller et al. (2017b). These differences in the inactivation rates may be due to one or more different factors between the New York and the current California trial: bacterial isolates and starting concentrations, soil composition, field design, irrigation practices, and weather conditions. For instance, foliar irrigation was used in our trial while in contrast, a rainfall event occurred in the New York trial, with substantial differences in the rate and total volume of received water. Our California trial applied approximately $3.7 \times$ and $3.4 \times$ more water in July-August and October, respectively, compared to the largest rain event in the Weller et al. (2017b) trial. Water droplet size and application rates could also affect bacterial detachment and/or growth trajectories; the rain event described by Weller et al. (2017b) occurred over five hours with an intensity of $1.42 \mathrm{~mm} \mathrm{rain/h}$ while the California irrigation events occurred over $2.5 \mathrm{~h}$ with a 9.35 and $9.65 \mathrm{~mm} / \mathrm{h}$ application rate in July-August and October. Weller et al. (2017b) found that the occurrence of a precipitation event increased the rate of inactivation from $0.32-$ to $1.08-\log$ E. coli $\mathrm{MPN}$ day $^{-1}$; we observed a rapid increase in bacterial concentration immediately following inoculation followed by a gradual decline of $0.11-\log$ E. coli MPN day $^{-1}$ mean inactivation prior to irrigation $(\mathrm{t}=1$ through $\mathrm{t}=5)$, with an average inactivation rate of $0.76-\log$ E. coli $\mathrm{MPN}$ day ${ }^{-1}$ following irrigation $(\mathrm{t}=6$ through $\mathrm{t}=12)$. This substantial difference in the inactivation rate of E. coli on heads of lettuce between California and New York trials underscores the importance for collating or comparing data from different growing regions across the US in order to better model the 
326 regional risks of foodborne illness associated with the consumption of raw or minimally processed

327 produce.

Over the ten-day trial, we observed significant departure from a first-order inactivation process across all fecal matrices (pig, rabbit, chicken) and seasons (July-August and October), in part caused by multi-log regrowth of bacteria following foliar irrigation. As a result, when modeling these kinetics, we used a categorized time variable to fully capture the time-dependent inactivation and regrowth of $E$. coli O157:H7 (Fig. 1). Nonetheless, some general features of bacterial inactivation are evident. Although a relatively uniform slurry inoculum was generated between fecal matrices and season (Table 1), a wide range of bacterial concentrations were recovered during each sampling event with similar variability across both trials (Fig. 1), consistent with the findings reported by Chase et al. (2017). Apparently, despite the lettuce being in the same plot and inoculated with the same strain of E. coli O157:H7, either the microenvironment, leaf surface microbiome, availability of nutrients, exposure to solar radiation, or other factor(s) differed enough from head to head that we observed a 4- to 6-log difference in $C_{t}$ within a few days of inoculation (Fig. 1). This level of variability in the level of E. coli $\mathrm{O} 157: \mathrm{H} 7$ on lettuce heads could translate to a wide variability in risk of illness from consumption of these lettuce heads, at least 3 orders of magnitude based on the dose response function of Teunis et al. (2008). The actual risk of human infection from consuming these heads of lettuce will also be dependent on factors such as trimming outer leaves during harvest, field packing method, retail and consumer handling practices, and serving size that collectively impact the final ingested dose relative to $\mathrm{C}_{\mathrm{t}}$. microbiology data, but has been used successfully to model microbial concentrations for a variety of food

347 matrices and environmental samples, such as E. coli $\mathrm{O} 157: \mathrm{H} 7$ concentrations on heads of lettuce due to

348 fecal splash from foliar irrigation (Atwill et al. 2015) and survival (Chase et al. 2017), concentrations of

349 Giardia duodenalis in dairy farm runoff (Miller et al. 2007), and E. coli concentrations in irrigation water 350 from leafy green produce farms (Benjamin et al. 2013). Negative binomial regression is well suited to 351 handle the variance of highly right-skewed and overly dispersed bacterial count data (e.g., Fig. 1) 
352 compared to Poisson or normal (Gaussian) regression which either constrain the variance to equal the

353 mean (Hilbe 2008) or require the variance to be independent of the mean and homoscedastic,

354 respectively. Equally important, negative binomial regression avoids the use of log-transformed data

355 compared to log-normal regression common to many analyses in food science (McKellar et al. 2014);

356 analyses based on log-transformed data can be negatively biased when used to make microbial predictions

357 on non-log-transformed data due to the phenomena known to some as Jensen's Inequality (Casella \&

358 Berger 1990; Feng et al. 2013).

$359 \quad$ Medicine \& Council (2003) indicate that caution should be used when utilizing statistical models

360 to analyze dynamic bacterial data with the goal of informing food safety policies. Fakruddin et al. (2011)

361 states that overall trends in microbial population data can be explained using statistical models, however,

362 the results should not be extrapolated beyond the environmental or temporal conditions defined within a

363 study. Rather than use negative binomial regression for modeling bacterial counts as was done with this

364 study, other investigators such as McKellar et al. (2014) and Weller et al. (2017b) have used Weibull

365 (survival) analysis to model the rate of change of a bacterial population on a head of lettuce. Survival

366 analysis was designed to observe defined events occurring to an individual over a defined time interval

367 (Gail 2000; Stevenson 2007). Due to short generations times, cell division, and uncertainty in tracking

368 individual cells across time to allow for proper calculation of time-in-study, estimating the survival

369 function on replicating bacterial populations would be equivalent to predicting survival functions of an

370 individual based on events of their great $n^{\text {th }}$ grandchild. This approach of using survival analysis, in

371 addition to the use of negative binomial, Poisson, and other such regression methods like log-normal, are

372 effectively interval-censored which can result in an underestimation of the true time-to-bacterial decay

373 (Abernethy 1996; Cain et al. 2011; Hougaard 1999; Kleinbaum \& Klein 2011). While analytical methods

374 have been developed to handle interval-censored survival data (Huang \& Wellner 1997), these methods

375 still require that the status of an event is measured at the individual scale level, which is currently not

376 feasible economically or technically for dynamic bacterial populations in field-based trials. 
Averaged across the three fecal matrices, we observed a 2.6- and 3.2-log reduction compared to

378

initial concentrations $\left(\mathrm{C}_{0}\right)$ in July and October, respectively (Table 1, Fig. 1). A previous study conducted in the Salinas Valley with the same strain of attenuated E. coli $\mathrm{O} 157: \mathrm{H} 7$ on romaine lettuce inoculated in a rabbit fecal slurry observed a 2.3-log reduction over $92 \mathrm{~h}$ (3.8 days), which equates to $\sim 0.6 \log$ MPN day $^{-1}$ (Chase et al. 2017) or about twice as large as the rate found in the current study. This $\sim 2$-fold difference in the inactivation rate can be explained in part due to the mid-trial irrigation occurring in this 10-day trial but was absent in the previous 4-day trial by Chase et al. (2017). Moreover, the daily varying concentrations of recovered E. coli $\mathrm{O} 157: \mathrm{H7}$ were significantly associated with leaf wetness (24-hour-toharvest average) leading to the higher order regression equations; the recovered E. coli $\mathrm{O} 157: \mathrm{H} 7$ concentrations and leaf wetness followed similar fluctuating trajectories (Table 1, Fig. 1). Interestingly, leaf wetness in July one-day post-irrigation was significantly higher $(P=0.0114)$ than the average wetness observed in October with the corresponding E. coli O157:H7 concentration also significantly higher $(P=0.0309)$ in July. Our findings regarding regrowth of E. coli $\mathrm{O} 157: \mathrm{H} 7$ following exposure to either higher levels of leaf wetness or foliar irrigation are consistent with the findings reported by Scherber et al. (2009) who observed bacterial cell membrane reconstruction leading to cell proliferation and colony formation within one-day of adequate rehydration. We speculate that a portion of the bacterial populations were washed off during irrigation, however, given adequate time after rehydration, the populations grew exponentially as evidenced by the $C_{t}$ immediately following irrigation in October with an average of $5.91 \times 10^{5} \mathrm{MPN} / \mathrm{head}$ compared to the samples collected $\sim 3.5 \mathrm{~h}$ post-irrigation during the July trial with an average of $1.60 \times 10^{9} \mathrm{MPN} /$ head (Fig. 1). Interestingly, the average bacterial concentrations collected immediately after irrigation (Oct. $\left.\mathrm{C}_{\mathrm{t}=7}\right)$ could be used to approximate the concentrations recovered 3.5 hours post irrigation (July $\mathrm{C}_{\mathrm{t}=7}$ ) using the bacterial growth calculation described by Todar (2008).

$$
B_{\text {final }}=b_{\text {initial }} \times 2^{n(\text { gen time })} \rightarrow\left(5.91 \times 10^{5}\right) \times\left(2^{11}\right)=1.21 \times 10^{9} \cong 1.60 \times 10^{9}
$$


401 The multi-log regrowth and the ability for bacterial cells to recover with adequate rehydration poses

402 challenges for produce safety risk management. However, our data also demonstrates, that the potential

403 food safety microbial risk may be eliminated or reduced when adequate time for bacterial inactivation

404 following an irrigation event is given.

405 Curtis (1943) found that guttation on the surface of lettuce is atypical and instead of forming dew-

406 like droplets, the excreted xylem fluids that contain a mixture of organic and inorganic compounds tend to

407 spread and aggregate over the surface of a lettuce leaf. Brandl \& Amundson (2008) reported a near 4-log

408 increase of E. coli $\mathrm{O} 157: \mathrm{H} 7$ concentrations when bacteria were grown for ten hours in extruded

409 compounds collected after the guttation process from romaine lettuce. Warm water-saturated soils

410 coupled with high humidity in the absence of sunlight have been shown to promote guttation (Ivanoff

411 1963). Mean nighttime humidity significantly decreased by $13.7 \%(P<0.001)$ from the July trial $(\hat{x}$

$412=93.3 \pm 2.1 \%, n=41)$ compared to the October trial $(\hat{x}=79.6 \pm 6.8 \%, n=45)$, and mean soil

413 temperature in the 24 hours leading up to irrigation was significantly warmer $\left(4.5^{\circ} \mathrm{C}, P<0.0000\right)$ during

414 the July trial $\left(\hat{x}=21.2 \pm 0.3^{\circ} \mathrm{C}, n=24\right)$ compared to the cooler soils of the October trial $(\hat{x}$

$\left.415=16.6 \pm 0.2^{\circ} \mathrm{C}, n=24\right)$. Soil water saturation was not measured during our trial, however, about $7.5 \%$

416 more irrigation water was applied in July $(2.59 \mathrm{~cm})$ compared to October $(2.41 \mathrm{~cm})$. We speculate that the

417 conditions for guttation occurred following irrigation, particularly during the July-August trial which

418 would help explain the significant difference in mean growth observed on day $6(t=8)$ between the two

419 trials. Furthermore, it is important to note that the application of irrigation is not uniform within an

420 agricultural field (CDWR 1999), which could also help explain, in part, the observed variability on

421 bacterial concentrations per head of lettuce during these trials.

422 Putting these findings into a pre-harvest food safety perspective, it has been shown that foliar

423 irrigation can act as a vector to transfer bacterial contamination in the form of fecal splash and/or furrow

424 water splash onto the leaves of adjacent lettuce when scat or other fecal matrices are present in the furrow

425 or on the soil surface of beds of lettuce (Atwill et al. 2015; Monaghan \& Hutchison 2012). Results from

426 this study indicate that E. coli $\mathrm{O} 157: \mathrm{H} 7$, when in the presence of a fecal slurry consistent with fecal 
427 splash, can possibly grow an additional 1- to 5-log on lettuce over the initial inoculum concentrations and

428 result in substantial microbial risk if harvest occurs within several days after irrigation. During this

429 experiment, there was substantial pathogen-reduction ( $>2-\log )$ after ten days when compared to initial

430 bacterial concentrations, or up to 7-log reduction following the peak concentrations occurring the day

431 after foliar irrigation. While our starting bacterial concentrations were consistent with a worst case

432 contamination scenario and likely unrealistic, this high inoculum level is consistent with concentrations

433 seen in super shedder cattle excreting $>10^{4}$ E. coli O157:H7 CFU/g feces (Munns et al. 2016). Moreover,

434 the use of high inoculum concentrations primarily influences the value of intercept term in a regression

435 model, not the value of the coefficients for such processes as inactivation or bacterial growth secondary to

436 leaf wetness unless such processes are dependent on initial bacterial concentration. Nonetheless, these

437 results should be interpreted with the appropriate level of caution.

438

439

440

441

442

443

444

445

446

447

448

\section{Acknowledgements}

450 We sincerely thank David Oryang, U.S. Food and Drug Administration, for constructive comments on 451 our study design, data interpretation, and the draft manuscript, and thank Jane Van Doren, U.S. Food and

452 Drug Administration, for thoughtful edits to the final draft of this manuscript. We would also like to thank 
453 Dr. Linda Harris and Anne-Laure Moyne for initial project planning and coordination of field logistics

454 along with data sharing. We would also like to thank the following UC Davis collaborator who provided 455 the fresh fecal samples used in this experiment: Kerry Mello at TRACS (rabbit), Jackie Pisenti at the 456 Avian Facilities (chicken) and Kent Parker at the Swine Center (pig). In addition, laboratory and field 457 assistance was provided by, Kristine Fernandez, Elaine Wang, Panachon Lor, Claudia Bonilla, Jon 458 Molina, Tran Nguyen, Elizabeth Antaki, Chengling Xiao, Anyarat Thiptara, Fhon Saharuetai, Lexi 459 Fisher, Yingjia Benson, and Melinda Fuabel.

460

\section{Conflict of Interest}

462 No conflict of interest declared 
463

464

465

466

467

468

469

470

471

472

473

474

475

476

477

478

479

480

481

482

483

484

485

486

487

488

489

490

491

492

493

494

495

496

497

498

499

500

501

502

503

504

505

506

507

508

\section{REFERENCES}

Abernethy RB. 1996. The New Weibull Handbook: R.B. Abernethy.

Atwill ER, Chase JA, Oryang D, Bond RF, Koike ST, Cahn MD, Anderson M, Mokhtari A, and Dennis S. 2015. Transfer of Escherichia coli O157:H7 from simulated wildlife scat onto romaine lettuce during foliar irrigation. J Food Prot 78:240-247. 10.4315/0362-028X.JFP-14-277

Barker-Reid F, Harapas D, Engleitner S, Kreidl S, Holmes R, and Faggian R. 2009. Persistence of Escherichia coli on injured iceberg lettuce in the field, overhead irrigated with contaminated water. J Food Prot 72:458-464.

Benjamin L, Atwill ER, Jay-Russell M, Cooley M, Carychao D, Gorski L, and Mandrell RE. 2013. Occurrence of generic Escherichia coli, E. coli $\mathrm{O} 157$ and Salmonella spp. in water and sediment from leafy green produce farms and streams on the Central California coast. Int J Food Microbiol 165:65-76. 10.1016/j.ijfoodmicro.2013.04.003

Brandl MT, and Amundson R. 2008. Leaf age as a risk factor in contamination of lettuce with Escherichia coli 0157:H7 and Salmonella enterica. Applied and Environmental Microbiology 74:2298-2306. 10.1128/aem.02459-07

Cain KC, Harlow SD, Little RJ, Nan B, Yosef M, Taffe JR, and Elliott MR. 2011. Bias Due to Left Truncation and Left Censoring in Longitudinal Studies of Developmental and Disease Processes. American Journal of Epidemiology 173:1078-1084. 10.1093/aje/kwq481

California Department of Water Resources [CDWR]. 1999. Water Facts: Evapotranspiration and Crop Requirements. State of California. THe Resources Agency. Department of Water Resources.

Casella G, and Berger RL. 1990. Statistical Inference: Brooks/Cole Publishing Company.

CDC. 2017. Surveillance for Foodborne Disease Outbreaks, United States, 2015, Annual Report. In: Daniel Dewey-Mattia KM, Julia Chen, Hannah Kisselburgh, Caroline Pilewski, Preethi Sundararaman, and Samuel Crowe editor. Atlanta, Georgia: Centers for Disease Control and Prevention.

Chase JA, Atwill ER, Partyka ML, Bond RF, and Oryang D. 2017. Inactivation of Escherichia coli O157:H7 on romaine lettuce when inoculated in a fecal slurry matrix. Journal of Food Protection 80:792798. 10.4315/0362-028x.jfp-16-307

Curiale M. MPN Calculator, Build 23. Available at http://membernyc.net/mcuriale/mpn/index.html. Curtis LC. 1943. Deleterious effects of Guttated Fluids on Foliage. American Journal of Botany 30:778782. doi:10.1002/j.1537-2197.1943.tb10330.x

Erickson MC, Webb CC, Diaz-Perez JC, Phatak SC, Silvoy JJ, Davey L, Payton AS, Liao J, Ma L, and Doyle MP. 2010. Surface and Internalized Escherichia coli 0157:H7 on Field-Grown Spinach and Lettuce Treated with Spray-Contaminated Irrigation Water. J Food Prot 73:1023-1029.

Fakruddin M, Mazumder RM, and Mannan KSB. 2011. Predictive microbiology: Modeling microbial responses in food. Ceylon Journal of Science 40.

Falardeau J, Johnson RP, Pagotto F, and Wang S. 2017. Occurrence, characterization, and potential predictors of verotoxigenic Escherichia coli, Listeria monocytogenes, and Salmonella in surface water used for produce irrigation in the Lower Mainland of British Columbia, Canada. PloS one 12:e0185437. 10.1371/journal.pone.0185437

Feng C, Wang H, Lu N, and Tu XM. 2013. Log transformation: application and interpretation in biomedical research. Statistics in Medicine 32:230-239. 10.1002/sim.5486

Fonseca JM, Fallon SD, Sanchez CA, and Nolte KD. 2011. Escherichia coli survival in lettuce fields following its introduction through different irrigation systems. J Appl Microbiol 110:893-902. 10.1111/j.1365-2672.2011.04942.x 
509

510

511

512

513

514

515

516

517

518

519

520

521

522

523

524

525

526

527

528

529

530

531

532

533

534

535

536

537

538

539

540

541

542

543

544

545

546

547

548

549

550

551

552

553

554

555

556

Franz E, Semenov AV, and Van Bruggen AHC. 2008. Modelling the contamination of lettuce with Escherichia coli 0157:H7 from manure-amended soil and the effect of intervention strategies. $J$ Appl Microbiol 105:1569-1584. doi:10.1111/j.1365-2672.2008.03915.x

Gail MH. 2000. Survival Analysis, Overview. In: Gail MH, and Benichou J, eds. Encyclopedia of Epidemiologic Methods: Wiley.

Gorski L, Cooley MB, Quinones B, Oryang D, and Mandrell RE. 2014. Prevalence of shigatoxin producing Escherichia coli, Salmonella enterica and Listeria monocytogenes at public access watershed sites in a California Central Coast agricultural region. Frontiers in Cellular and Infection Microbiology 4:1. 10.3389/fcimb.2014.00058

Hilbe JM. 2008. Negative Binomial Regression: Cambridge University Press.

Hougaard P. 1999. Fundamentals of Survival Data. Biometrics 55:13-22. doi:10.1111/j.0006341X.1999.00013.x

Huang J, and Wellner JA. 1997. Interval Censored Survival Data: A Review of Recent Progress. In: Lin DY, and Fleming TR, editors. Proceedings of the First Seattle Symposium in Biostatistics. New York, NY: Springer US. p 123-169.

Ivanoff SS. 1963. Guttation Injuries of Plants. Botanical Review 29:202-229.

Jarvis B, Wilrich C, and Wilrich PT. 2010. Reconsideration of the derivation of most probable numbers, their standard deviations, confidence bounds and rarity values. Journal of Applied Microbiology 109:1660-1667. 10.1111/j.1365-2672.2010.04792.x

Kleinbaum DG, and Klein M. 2011. Survival Analysis, a Self-Learning Text: Springer.

McKellar RC, Peréz-Rodríguez F, Harris L, Moyne A-I, Blais B, Topp E, Bezanson G, Bach S, and Delaquis P. 2014. Evaluation of different approaches for modeling Escherichia coli O157:H7 survival on field lettuce. Int J Food Microbiol 184:74-85. http://dx.doi.org/10.1016/j.ijfoodmicro.2014.04.026

Medicine lo, and Council NR. 2003. Scientific Criteria to Ensure Safe Food. Washington, DC: The National Academies Press.

Miller WA, Lewis DJ, Lennox M, Pereira MG, Tate KW, Conrad PA, and Atwill ER. 2007. Climate and onfarm risk factors associated with Giardia duodenalis cysts in storm runoff from California coastal dairies. Appl Environ Microbiol 73:6972-6979. 10.1128/aem.00100-07

Monaghan JM, and Hutchison ML. 2012. Distribution and decline of human pathogenic bacteria in soil after application in irrigation water and the potential for soil-splash-mediated dispersal onto fresh produce. Journal of Applied Microbiology 112:1007-1019. 10.1111/j.13652672.2012.05269.x

Mootian G, Wu WH, and Matthews KR. 2009. Transfer of Escherichia coli 0157:H7 from soil, water, and manure contaminated with low numbers of the pathogen to lettuce plants. J Food Prot 72:23082312.

Moyne A-I, Sudarshana MR, Blessington T, Koike ST, Cahn MD, and Harris LJ. 2011. Fate of Escherichia coli 0157:H7 in field-inoculated lettuce. Food Microbiol 28:1417-1425. http://dx.doi.org/10.1016/j.fm.2011.02.001

Munns KD, Zaheer R, Xu Y, Stanford K, Laing CR, Gannon VPJ, Selinger LB, and McAllister TA. 2016. Comparative Genomic Analysis of Escherichia coli O157:H7 Isolated from Super-Shedder and Low-Shedder Cattle. PloS one 11:e0151673. 10.1371/journal.pone.0151673

Partyka ML, Bond RF, Chase JA, and Atwill ER. 2017. Monitoring bacterial indicators of water quality in a tidally influenced delta: A Sisyphean pursuit. Sci Total Environ 578:346-356. 10.1016/j.scitotenv.2016.10.179

Partyka ML, Bond RF, Chase JA, and Atwill ER. 2018a. Spatial and temporal variability of bacterial indicators and pathogens in six California reservoirs during extreme drought. Water research 129:436-446. https://doi.org/10.1016/j.watres.2017.11.038 
557

558

559

560

561

562

563

564

565

566

567

568

569

570

571

572

573

574

575

576

577

578

579

580

581

582

583

584

585

586

587

588

589

590

591

592

593

594

595

596

597

598

599

600

601

602

603

Partyka ML, Bond RF, Chase JA, and Atwill ER. 2018b. Spatiotemporal Variability in Microbial Quality of Western Agricultural Water Supplies: A Multistate Study. Journal of Environmental Quality 47:p. 939-948. 10.2134/jeq2017.12.0501

Partyka ML, Bond RF, Chase JA, Kiger L, and Atwill ER. 2016. Multistate evaluation of microbial water and sediment quality from agricultural recovery basins. Journal of Environmental Quality 45:657665. 10.2134/jeq2015.06.0323

Richardson LC, Bazaco MC, Parker CC, Dewey-Mattia D, Golden N, Jones K, Klontz K, Travis C, Kufel JZ, and Cole D. 2017. An Updated Scheme for Categorizing Foods Implicated in Foodborne Disease Outbreaks: A Tri-Agency Collaboration. Foodborne Pathog Dis 14:701-710. 10.1089/fpd.2017.2324

Scherber CM, Schottel JL, and Aksan A. 2009. Membrane phase behavior of Escherichia coli during desiccation, rehydration, and growth recovery. Biochimica et Biophysica Acta (BBA) Biomembranes 1788:2427-2435. https://doi.org/10.1016/j.bbamem.2009.08.011

Solomon EB, Pang H-J, and Matthews KR. 2003. Persistence of Escherichia coli O157:H7 on Lettuce Plants following Spray Irrigation with Contaminated Water. J Food Prot 66:2198-2202.

Solomon EB, Potenski CJ, and Matthews KR. 2002a. Effect of Irrigation Method on Transmission to and Persistence of Escherichia coli O157:H7 on Lettuce. J Food Prot 65:673-676.

Solomon EB, Yaron S, and Matthews KR. 2002b. Transmission of Escherichia coli O157:H7 from Contaminated Manure and Irrigation Water to Lettuce Plant Tissue and Its Subsequent Internalization. Appl Environ Microbiol 68:397-400. 10.1128/AEM.68.1.397-400.2002

Ssemanda JN, Reij MW, van Middendorp G, Bouw E, van der Plaats R, Franz E, Muvunyi CM, Bagabe MC, Zwietering $\mathrm{MH}$, and Joosten $\mathrm{H}$. 2018. Foodborne pathogens and their risk exposure factors associated with farm vegetables in Rwanda. Food Control 89:86-96. https://doi.org/10.1016/j.foodcont.2017.12.034

Steele $\mathrm{M}$, and Odumeru J. 2004. Irrigation water as source of foodborne pathogens on fruit and vegetables. Journal of Food Protection 67:2839-2849.

Stevenson M. 2007. An Introduction to Survival Analysis. Available at http://www.biecek.pl/statystykaMedyczna/Stevenson_survival_analysis_195.721.pdf.

Teunis PFM, Ogden ID, and Strachan NJC. 2008. Hierarchical dose response of E. coli $\mathrm{O} 157$ : $\mathrm{H} 7$ from human outbreaks incorporating heterogeneity in exposure. Epidemiology and Infection 136:761770. 10.1017/s0950268807008771

Todar K. 2008. Todar's Online Textbook of Bacteriology.

Van Der Linden I, Cottyn B, Uyttendaele M, Berkvens N, Vlaemynck G, Heyndrickx M, and Maes M. 2014. Enteric Pathogen Survival Varies Substantially in Irrigation Water from Belgian Lettuce Producers. International Journal of Environmental Research and Public Health 11:10105-10124. 10.3390/ijerph111010105

Wachtel MR, Whitehand LC, and Mandrell RE. 2002. Association of Escherichia coli O157:H7 with preharvest leaf lettuce upon exposure to contaminated irrigation water. J Food Prot 65:18-25.

Wang Y, Pandey P, Zheng Y, Atwill ER, and Pasternack G. 2018. Particle attached and free floating pathogens survival kinetics under typical stream and thermal spring temperature conditions. Amb Express 8:100. 10.1186/s13568-018-0626-z

Weller DL, Kovac J, Kent DJ, Roof S, Tokman JI, Mudrak E, Kowalcyk B, Oryang D, Aceituno A, and Wiedmann M. 2017a. Escherichia coli transfer from simulated wildlife feces to lettuce during foliar irrigation: A field study in the Northeastern United States. Food Microbiol 68:24-33. https://doi.org/10.1016/j.fm.2017.06.009

Weller DL, Kovac J, Roof S, Kent DJ, Tokman JI, Kowalcyk B, Oryang D, Ivanek R, Aceituno A, Sroka C, and Wiedmann M. 2017b. Survival of Escherichia coli on lettuce under field conditions encountered 
604

605

606 in the northeastern United States. Journal of Food Protection 80:1214-1221. 10.4315/0362028x.Jfp-16-419 


\section{Table $\mathbf{1}$ (on next page)}

Mean concentrations and log-reductions of $\mathrm{E}$. coli $0157: H 7^{\mathrm{a}}$ recovered on romaine lettuce over two 236 h field trials in central coastal California, 2012.

${ }^{a}$ Data for day $0.1,5,6$, and 10 post-inoculation shown

${ }^{\mathrm{b}}$ Samples below the limit of detection were assigned a value of $248 \mathrm{MPN} / \mathrm{head}$, samples exceeding the limit were assigned a value of $3.45 \times 10^{12} \mathrm{MPN} /$ head

'Cumulative volume $(\mathrm{cm})$ range of applied irrigation water during the mid-trial irrigation events occurring on day 5, measured with rain gauges placed throughout the field

${ }^{\mathrm{d}} \mathrm{C}_{\max }$ occurred on day 6 of all trials $(t=8)$ 
1 Table 1. Mean concentrations and log-reductions of E. coli O157:H7 recovered on romaine lettuce

2 over two 236 h field trials in central coastal California, 2012.

\begin{tabular}{|c|c|c|c|c|c|c|c|c|}
\hline $\begin{array}{l}\text { Fecal } \\
\text { Type }\end{array}$ & $\begin{array}{c}\% \\
\text { pos. } \\
\text { (n) }\end{array}$ & $\begin{array}{c}\text { Applied } \\
\text { CFU/head } \\
\left(\mathbf{C}_{0}\right)\end{array}$ & $\begin{array}{l}C_{t=1} \text { day } 0.1 \\
\text { MPN/head }\end{array}$ & $\begin{array}{c}C_{t=6} \text { day } 5 \\
\text { MPN/head }\end{array}$ & $\begin{array}{c}C_{t=8} \text { day } 6 \\
\text { MPN/head }\end{array}$ & $\begin{array}{l}C_{t=12} \text { day } 10 \\
\text { MPN/head }\end{array}$ & $\begin{array}{c}\log \left(C_{t=12} /\right. \\
\left.C_{0}\right)\end{array}$ & $\begin{array}{c}\log \left(C_{t=12} /\right. \\
\left.C_{\text {max }}\right)^{d}\end{array}$ \\
\hline & \multicolumn{8}{|c|}{ July 27-Aug 6, Irrigation on Aug 1, 1.3-3.9 $\mathrm{cm}^{\mathrm{c}}$} \\
\hline Pig & $\begin{array}{l}100 \% \\
\left(95^{\mathrm{b}}\right)\end{array}$ & $3.78 \times 10^{7}$ & $7.64 \times 10^{8}$ & $3.31 \times 10^{8}$ & $8.76 \times 10^{11}$ & $6.29 \times 10^{4}$ & -2.78 & -7.14 \\
\hline Rabbit & $\begin{array}{c}100 \% \\
(96)\end{array}$ & $3.76 \times 10^{7}$ & $7.11 \times 10^{8}$ & $7.99 \times 10^{6}$ & $4.10 \times 10^{10}$ & $7.51 \times 10^{4}$ & -2.70 & -5.74 \\
\hline \multirow[t]{2}{*}{ Chicken } & $\begin{array}{c}100 \% \\
\left(96^{\mathrm{b}}\right)\end{array}$ & $4.17 \times 10^{7}$ & $1.59 \times 10^{8}$ & $7.69 \times 10^{6}$ & $4.31 \times 10^{11}$ & $1.53 \times 10^{5}$ & -2.44 & -6.45 \\
\hline & \multicolumn{8}{|c|}{ Oct 16-Oct 26, Irrigation on Oct $21,1.3-2.2 \mathrm{~cm}^{\mathrm{c}}$} \\
\hline Pig & $\begin{array}{l}100 \% \\
\left(94^{\mathrm{b}}\right)\end{array}$ & $4.56 \times 10^{7}$ & $1.02 \times 10^{8}$ & $1.53 \times 10^{5}$ & $8.75 \times 10^{9}$ & $1.24 \times 10^{4}$ & -3.56 & -5.85 \\
\hline Rabbit & $\begin{array}{c}100 \% \\
\left(96^{\mathrm{b}}\right)\end{array}$ & $5.00 \times 10^{7}$ & $6.72 \times 10^{8}$ & $2.99 \times 10^{6}$ & $4.35 \times 10^{7}$ & $4.27 \times 10^{4}$ & -3.07 & -3.01 \\
\hline Chicken & $\begin{array}{c}100 \% \\
\left(95^{\mathrm{b}}\right)\end{array}$ & $3.03 \times 10^{7}$ & $4.95 \times 10^{8}$ & $5.77 \times 10^{5}$ & $1.01 \times 10^{8}$ & $1.82 \times 10^{4}$ & -3.22 & -3.74 \\
\hline
\end{tabular}

3

${ }^{a}$ Data for day 0.1, 5, 6, and 10 post-inoculation shown

${ }^{\mathrm{b}}$ Samples below the limit of detection were assigned a value of $248 \mathrm{MPN} / \mathrm{head}$, samples exceeding the limit were assigned a value of $3.45 \times 10^{12} \mathrm{MPN} / \mathrm{head}$

${ }^{\mathrm{c}}$ Cumulative volume $(\mathrm{cm})$ range of applied irrigation water during the mid-trial irrigation events occurring on day 5, measured with rain gauges placed throughout the field

${ }^{\mathrm{d}} C_{\text {max }}$ occurred on day 6 of all trials $(t=8)$ 


\section{Table 2 (on next page)}

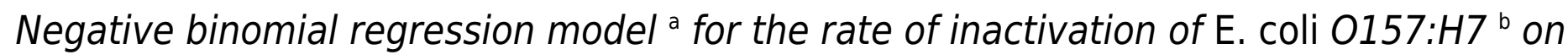
heads of romaine lettuce $(n=559)$ over 10 days in central coastal California during JulyAug. and Oct., 2012.

${ }^{\text {a }}$ Regressed onto $C_{t}$ as the outcome variable

${ }^{\mathrm{b}}$ Bacteria concentrations were estimated using MPN methods

${ }^{\mathrm{c}}$ Referent

${ }^{\mathrm{d}}$ Based on the averaged HOBO data collected in 15-min. intervals beginning $24 \mathrm{~h}$ prior to harvest

${ }^{\mathrm{e}}$ Categorized time since inoculation with actual hours displayed in parenthesis

${ }^{\mathrm{f}}$ Event 7 was modeled as two separate events to capture the $4.5 \mathrm{~h}$ collection lag between both trials 
2 Table 2. Negative binomial regression model a for the rate of inactivation of $\mathrm{E}$. coli $0157: H 7^{\mathrm{b}}$ on heads

3 of romaine lettuce ( $n=559)$ over 10 days in central coastal California during July-August and October,

\begin{tabular}{|c|c|c|c|c|c|}
\hline Factor & & Coefficient & Std. Err. & 95\% C.I. & P-value \\
\hline \multirow[t]{3}{*}{ Fecal } & $\operatorname{Pig}^{\mathrm{c}}$ & 0.0 & & & \\
\hline & Rabbit & -1.232 & 0.334 & $-1.888,-0.576$ & 0.000 \\
\hline & Chicken & -1.289 & 0.342 & $-1.959,-0.619$ & 0.000 \\
\hline \multirow[t]{2}{*}{ Trial } & July ${ }^{\mathrm{c}}$ & 0.0 & & & \\
\hline & October & -4.066 & 0.375 & $-4.801,-3.331$ & 0.000 \\
\hline \multirow[t]{3}{*}{ Trial $\times$ Fecal } & July $\times$ Pig $^{\mathrm{c}}$ & 0.0 & & & \\
\hline & October $\times$ Rabbit & 1.929 & 0.487 & $0.974,2.884$ & 0.000 \\
\hline & October $\times$ Chicken & 2.016 & 0.480 & $1.076,2.956$ & 0.000 \\
\hline Daily Leaf Wetness d & & 0.041 & 0.012 & $0.017,0.065$ & 0.001 \\
\hline \multirow[t]{13}{*}{ Sampling Event ${ }^{\mathrm{e}}$} & $1(0.5 \pm 0.3)^{\mathrm{c}}$ & 0.0 & & & \\
\hline & $2(21.8 \pm 0.8)$ & -0.657 & 0.391 & $-1.423,0.109$ & 0.093 \\
\hline & $3(44.6 \pm 0.1)$ & -1.565 & 0.490 & $-2.526,-0.605$ & 0.001 \\
\hline & $4(68.9 \pm 0.4)$ & -4.170 & 0.408 & $-4.97,-3.371$ & 0.000 \\
\hline & $5(93.2 \pm 0.5)$ & -5.642 & 0.408 & $-6.441,-4.842$ & 0.000 \\
\hline & $6(115.9 \pm 0.1)$ & -3.880 & 0.450 & $-4.762,-2.998$ & 0.000 \\
\hline & $7(119.5 \text { Oct. })^{\mathrm{f}}$ & -6.167 & 0.517 & $-7.179,-5.154$ & 0.000 \\
\hline & $7(123.0 \text { July })^{\mathrm{f}}$ & -0.133 & 0.655 & $-1.417,1.150$ & 0.839 \\
\hline & $8(141.7 \pm 0.5)$ & 3.215 & 0.462 & $2.308,4.121$ & 0.000 \\
\hline & $9(164.9 \pm 0.4)$ & -5.130 & 0.426 & $-5.965,-4.295$ & 0.000 \\
\hline & $10(188.5 \pm 0.5)$ & -7.180 & 0.419 & $-8.002,-6.359$ & 0.000 \\
\hline & $11(212.8 \pm 0.3)$ & -6.274 & 0.462 & $-7.179,-5.369$ & 0.000 \\
\hline & $12(235.4 \pm 0.6)$ & -9.230 & 0.396 & $-10.005,-8.454$ & 0.000 \\
\hline Intercept & & 2.997 & 0.754 & $1.520,4.474$ & 0.000 \\
\hline
\end{tabular}

42012.

$5 \quad$ a Regressed onto $C_{t}$ as the outcome variable

6 b Bacteria concentrations were estimated using MPN methods

$7 \quad$ c Referent

$8 \mathrm{~d}$ Based on the averaged HOBO data collected in 15-min. intervals beginning $24 \mathrm{~h}$ prior to harvest

$9 \quad{ }^{\mathrm{e}}$ Categorized time since inoculation with actual hours displayed in parenthesis

$10 \quad{ }^{\mathrm{f}}$ Event 7 was modeled as two separate events to capture the $4.5 \mathrm{~h}$ collection lag between both trials

11

12 
Figure 1 (on next page)

Regression model a for the inactivation rate of $\mathrm{E}$. coli 0157:H7 in pig fecal slurry on romaine lettuce grown in central coastal California during two 10-day field trials occurring in 2012.

a Model shown holding leaf wetness constant using the median values of $33 \%$ and $32 \%$ for the July-August and October, respectively. 


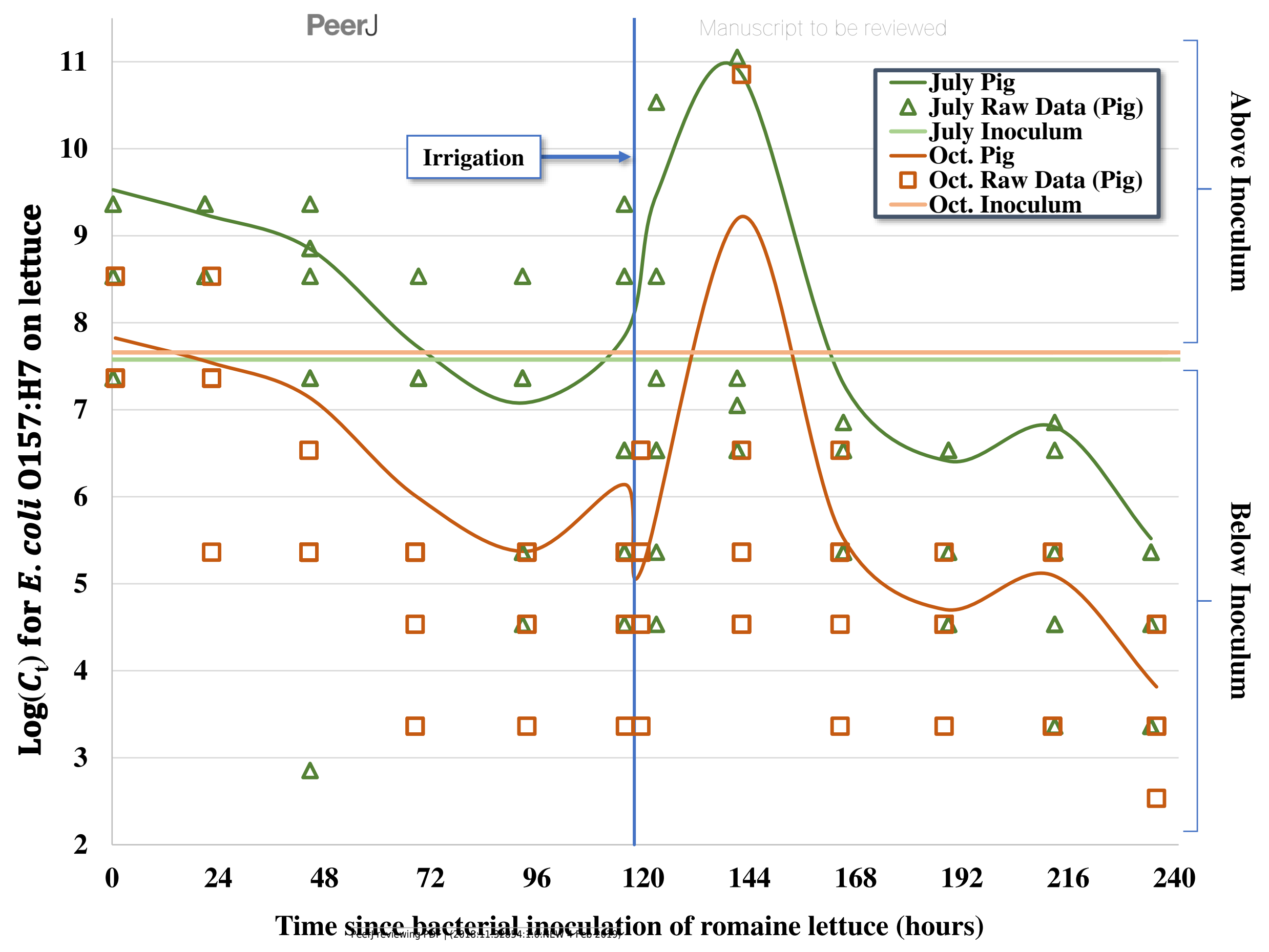


Figure 2 (on next page)

Predicted effect of leaf wetness on the inactivation rate of $\mathrm{E}$. coli 0157:H7 in pig fecal slurry on heads of romaine lettuce in central coastal California. 


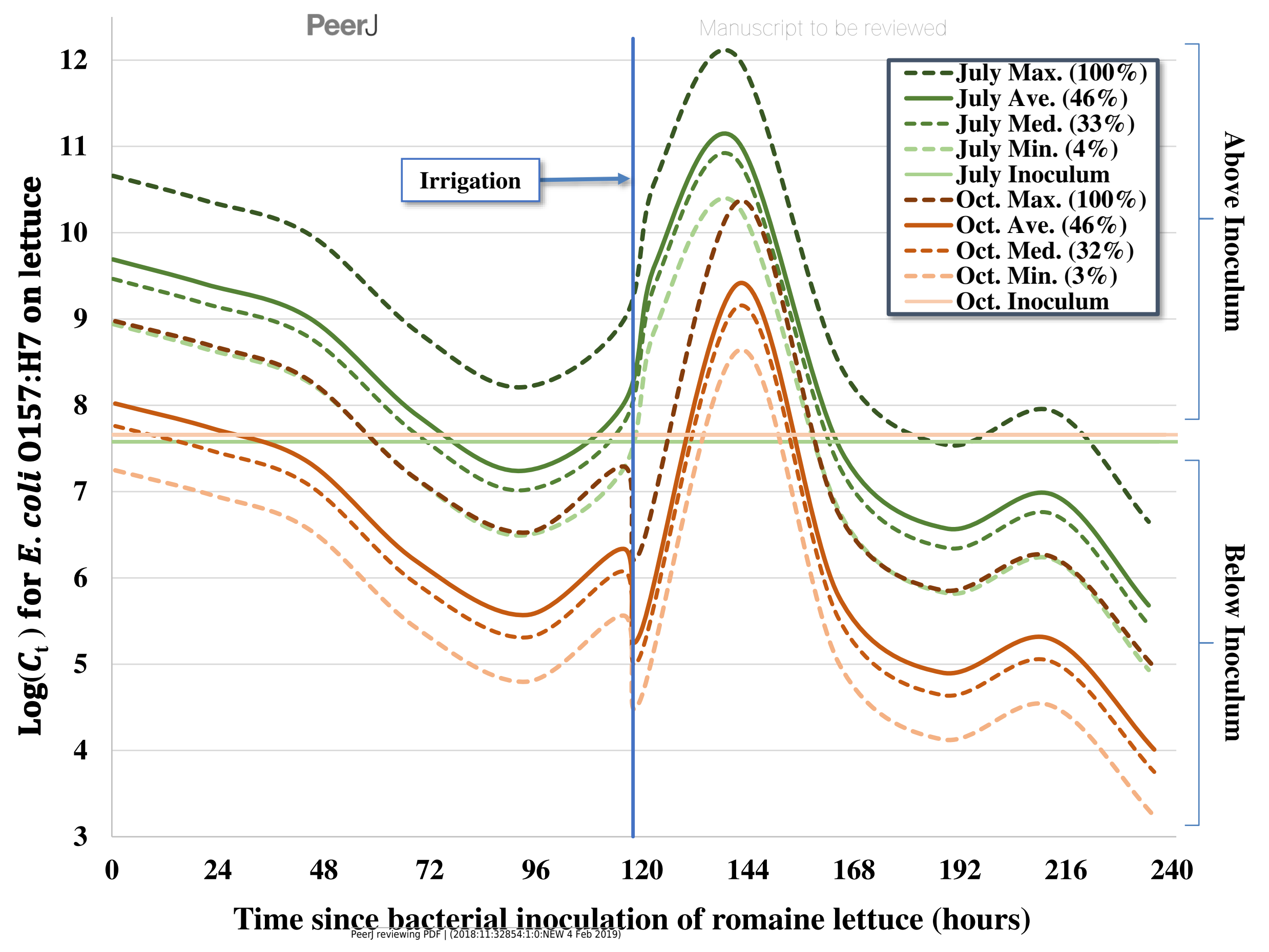

